\title{
CREB3L1 Gene
}

National Cancer Institute

\section{Source}

National Cancer Institute. CREB3L1 Gene. NCI Thesaurus. Code C95477.

This gene plays a role in transcriptional regulation in response to cellular stress. 